\author{
KAROL KICZKA \\ ORCID: 0000-0002-3056-024X \\ Uniwersytet Wrocławski \\ karol.kiczka@uwr.edu.pl
}

\title{
Niepomijalność Prezesa Urzędu Zamówień Publicznych w zamówieniach publicznych
}

\begin{abstract}
Abstrakt: Prawo zamówień publicznych jest częścią publicznego prawa gospodarczego, określaną w piśmiennictwie naukowym mianem prawa zarządu mieniem publicznym. Prawo zamówień publicznych z 2019 roku wzmacnia pozycję prawną Prezesa Urzędu w systemie zamówień publicznych w stosunku do stanu dotychczasowego. Niezależnie od tego do badanego porządku prawnego wprowadzono nowy organ administracji publicznej — Komitet do spraw Kontroli w Zamówieniach Publicznych. Wszystko to świadczy głównie o niepomijalności Prezesa Urzędu w zamówieniach publicznych w społecznej gospodarce rynkowej.
\end{abstract}

Słowa kluczowe: Prezes Urzędu Zamówień publicznych, zamówienia publiczne.

\section{Wprowadzenie}

Tematyka zamówień publicznych ma swoje podstawowe umocowanie w normach ustawy zasadniczej mających za przedmiot regulacji różnej kategorii mienie publiczne (aktywa publiczne) ${ }^{1}$. Środki finansowe na cele publiczne - jak stanowi Konstytucja RP — są gromadzone i wydatkowane w sposób określony w ustawie. Najwyższa Izba Kontroli kontroluje działalność organów administracji rządowej, Narodowego Banku Polskiego, państwowych osób prawnych i innych państwowych jednostek organizacyjnych z punktu widzenia legalności, gospodarności, celowości i rzetelności. Najwyższa Izba Kontroli może także kontrolować dzia-

1 Por. art. 3 ust. 1 pkt 12 ustawy z dnia 29 września 2019 roku o rachunkowości (Dz.U. z 2019 r. poz. 351 z późn. zm.). Zob. D. Kopiński, Teoretyczne podstawy globalnych dóbr publicznych (GDP), [w:] D. Kopiński, M. Wróblewski, Globalne dobra publiczne a organizacje międzynarodowe. Przypadek Banku Światowego i Międzynarodowego Funduszu Walutowego, Warszawa 2020, s. 15. 
łalność organów samorządu terytorialnego, komunalnych osób prawnych i innych komunalnych jednostek organizacyjnych z punktu widzenia legalności, gospodarności i rzetelności. Może również kontrolować z punktu widzenia legalności i gospodarności działalność innych jednostek organizacyjnych i podmiotów gospodarczych w zakresie, w jakim wykorzystują one majątek albo środki państwowe lub komunalne oraz wywiązują się z zobowiązań finansowych na rzecz państwa ${ }^{2}$.

Przytoczone przykładowo normy Konstytucji mają ważne znaczenie dla umiejscowienia tematyki zamówień publicznych na gruncie prawoznawstwa i w otoczeniu społeczno-gospodarczym. Są one kluczowe dla ustawodawcy zwykłego, ponieważ kształtują ustrojowe zasady prawidłowego zarządu mieniem publicznym, w tym zamówieniami publicznymi ${ }^{3}$. Podejście to zakłada, jak trafnie akcentuje Leon Kieres, przede wszystkim obecność konstytucji w systemie prawa oraz jej prymat wobec innych źródeł prawa w państwie ${ }^{4}$. Konstytucja jest zatem — jak pisał Tadeusz Bigo — założeniem i podstawą całego porządku prawnego i wszelkiej działalności państwowej. Ten charakter zaś przypisujemy konstytucji jako całości, nie wyłączając ogólnych postanowień rozdziału I (tak zwanego dekalogu). Przepisy dekalogu są bowiem czymś więcej niż teoretycznym wykładem ideologii. Jeśli niektóre z nich nie mają sprecyzowanej formy nakazów prawniczych, to w każdym razie zawierają wypowiedź oceny i wskazanie ogólne. Są normami interpretacyjnymi - jak zaznaczał dalej Bigo — które nie tylko z powodzeniem odgrywają rolę dyrektyw dla ustawodawcy, ale też — jak wykazała judykatura sądowa w okresie konstytucji marcowej — często mogą znaleźć bezpośrednie zastosowanie przy rozstrzyganiu konkretnych wypadków ${ }^{5}$.

Władza publiczna przede wszystkim w wyniku implementacji norm unijnych ustanowiła krajowe normy prawne, które kształtują fragment systemu prawa szczególny podsystem - jakim jest Prawo zamówień publicznych ${ }^{6}$ z zespolo-

2 Art. 216 ust. 1 i art. 203 Konstytucji Rzeczypospolitej Polskiej z dnia 2 kwietnia 1997 roku (Dz.U. Nr 78, poz. 483 ze zm.; dalej: Konstytucja RP, Konstytucja). Zob. A. Sajo, R. Uitz, The Constitution of Freedom. An Introduction to Legal Constitutionalism, Oxford 2017, s. 12; J. Gola, Między gospodarnościa a niegospodarnościa działań organów administracji gospodarczej, [w:] Państwo a przedsiębiorca - aktualne wyzwania, red. A. Borkowski, W. Małecki, Wrocław 2019, s. 157.

3 Por. S. Rozmaryn, Konstytucja jako ustawa zasadnicza Polskiej Rzeczypospolitej Ludowej, Warszawa 1961, s. 111; Z. Niewiadomski, System planowania i zagospodarowania przestrzennego a ustawy specjalne. Dezintegracja systemu? - tezy wstapienia, [w:] Specustawy inwestycyjno-budowlane, red. T. Bąkowski, Gdańsk 2020, s. 19. Zob. S.Z. Szyszkowski, Kapitały obrotowe w skomercjalizowanych przedsiębiorstwach państwowych, „Ruch Prawniczy, Ekonomiczny i Socjologiczny" 1929, pierwsze półrocze, s. 121.

${ }^{4}$ L. Kieres, Konstytucyjne publiczne prawo gospodarcze, [w:] M. Biliński et al., Wielka encyklopedia prawa, t. 17. Prawo publiczne gospodarcze, Warszawa 2019, s. 144.

5 T. Bigo, Wytyczne dla prawa administracyjnego w Konstytucji Polskiej r. 1935, Warszawa 1936, s. 3. Por. J. Boć, Konstytucja a prawo administracyjne, „Ruch Prawniczy, Ekonomiczny i Socjologiczny” 2011, nr 2, s. 70; B. Limperg, Zaufanie i rzady prawa, [w:] Przyszłość Europy opartej na rządach prawa, „Studia i Analizy Sądu Najwyższego. Materiały Naukowe” 8, 2019, s. 15-21.

${ }^{6}$ Ustawa z dnia 29 stycznia 2004 roku Prawo zamówień publicznych (Dz.U. Nr 19, poz. 177 z późn. zm.; dalej: p.z.p. 2004). Uprzednio ustawa z dnia 10 czerwca 1994 roku o zamówieniach 
nymi (powiązanymi) z nim aktami normatywnymi. Ustawa z dnia 11 września 2019 roku Prawo zamówień publicznych ${ }^{7}$ na mocy art. 1 ustawy z dnia 11 września 2019 roku Przepisy wprowadzające ustawę - Prawo zamówień publicznych (Dz.U. poz. 2020) wchodzi w życie z dniem 1 stycznia 2021 roku. Ustawa p.z.p. 2019 zastępuje uprzednio obowiązującą ustawę z dnia 29 stycznia 2004 roku Prawo zamówień publicznych. Projekt p.z.p. 2019 wniósł do Sejmu Prezes Rady Ministrów ${ }^{8}$, a celem dokumentu jest wykonanie prawa Unii Europejskiej. Do prezentowania stanowiska Rady Ministrów w toku prac parlamentarnych został upoważniony minister przedsiębiorczości i technologii (minister właściwy do spraw gospodarki).

Administracja publiczna w domenie zamówień publicznych występuje w różnych rolach: projektodawcy rozwiązań prawnych, legislatora, zamawiającego, wykonawcy, kontrolującego, kontrolowanego, nakładającego kary pieniężne itp. ${ }^{9}$

Celem opracowania jest wstępne ustalenie pozycji prawnej i zadań wybranego do analizy organu administracji publicznej - Prezesa Urzędu Zamówień Publicznych — w świetle p.z.p. 2019, który funkcjonuje w obszarze zamówień publicznych już od momentu wprowadzenia przedmiotowej regulacji do naszego porządku prawnego w 1994 roku. Należy zaznaczyć, że nie jest to jedyny organ władzy wykonawczej ulokowany tam przez ustawodawcę ${ }^{10}$. W opracowaniu wykorzystane zostaną właściwe źródła, zwłaszcza dokumenty procesu prawotwórczego, akty prawne i piśmiennictwo.

\section{Zamówienia publiczne w doktrynie i gospodarce}

Prawo zamówień publicznych obejmuje wypowiedzi normatywne - konstrukcje (instytucje) jurydyczne wywodzące się oraz odwołujące się do różnych gałęzi (dziedzin) porządku prawnego. Wzmiankowane zjawisko równoczesnego wdrażania przez normodawcę instytucji prawa publicznego i prawa prywatnego w określonych sferach stosunków społecznych jest od dawna odnotowywa-

publicznych (Dz.U. Nr 76, poz. 344 z późn. zm.; dalej: u.z.p. 1994). Por. K. Strzyczkowski, Prawa podstawowe jako źródło celów społecznych i gospodarczych Unii Europejskiej, [w:] Państwo a przedsiębiorca..., s. 233.

7 Ustawa z dnia 11 września 2019 roku Prawo zamówień publicznych (Dz.U. poz. 2019; dalej: p.z.p. 2019 lub nowa ustawa).

8 Prezes Rady Ministrów RM-10-122-19, druk nr 3624 z dnia 12 lipca 2019 roku.

9 Por. M. Guziński, Organy administracji publicznej jako podmioty zamówień publicznych, [w:] Między tradycja a przyszłościa w nauce prawa administracyjnego. Księa jubileuszowa Profesora Jana Bocia, red. J. Supernat, Wrocław 2009, s. 200-208; E. Przeszło, Rola organizacji przedsiębiorców w sferze zamówień publicznych, [w:] Państwo a przedsiębiorca..., s. 591.

10 Por. W. Dzierżanowski, Prawo do sądu w zamówieniach publicznych, Warszawa 2018, s. $233-269$. 
ne $\mathrm{i}$ analizowane $\mathrm{w}$ naukach prawnych ${ }^{11}$. Wykorzystywanie $\mathrm{w}$ danym obszarze prawa różnych rodzajów norm prawnych zarówno z punktu widzenia poznania naukowego (szczegółowych dyscyplin prawoznawstwa), jak i ich właściwości aplikacyjnych oraz egzekucyjnych prowadzi do wieloaspektowych następstw $\mathrm{w}$ życiu prawnym ${ }^{12}$.

Prawo zamówień publicznych przynależy do publicznego prawa gospodarczego, a dokładniej do jego fragmentu nazywanego w obiegu naukowym prawem zarządu mieniem publicznym. Prawo zarządu mieniem publicznym, jako element publicznego prawa gospodarczego, obejmuje normy prawne właściwe kształtowaniu uprawnień i obowiązków kierowanych do władających mieniem publicznym. Jak akcentuje L. Kieres: „Idzie tu o sposób zarządzania mieniem publicznym, o wykonywanie praw majątkowych państwa i innych podmiotów publicznych zgodnie z celami, jakim majątek ten ma służyć"13.

Nauka wywiodła z porządku prawego odnoszącego się do prawa zarządu mieniem publicznym specyficzną zasadę ${ }^{14}$ publicznego prawa gospodarczego - zasadę prawidłowego gospodarowania mieniem publicznym. Zgodnie $\mathrm{z}$ treścią tej zasady - jak uwypukla Adam Chełmoński ${ }^{15}$ — cały obszar wykonywania praw majątkowych państwa i innych podmiotów publicznoprawnych przez organy władzy publicznej podlega ocenie według, wskazanych wcześniej, ustalonych w Konstytucji kryteriów legalności, celowości, gospodarności i rzetelności ${ }^{16}$. Kryteria te są dla organu władzy publicznej dyrektywami działania, którymi powinien się kierować, gospodarując mieniem publicznym, mając na uwadze dobro publiczne (interes publiczny) i majątkowe interesy podmiotu, który reprezen-

11 Zob. T. Długosz et al., Funkcje administracji gospodarczej, [w:] System Prawa Administracyjnego, t. 8a. Publiczne prawo gospodarcze, red. J. Grabowski, L. Kieres, A. Walaszek-Pyzioł, Warszawa 2018, s. 691. Por. B. Hełczyński, Komercjalizacja przedsiębiorstw państwowych na tle polskich przepisów prawnych, Warszawa 1929.

12 J. Jeżewski, Administracja pod rzadem prawa cywilnego, Wrocław 1974; W.S. Sawczuk, Właściwość sadów administracyjnych i sądów powszechnych w sprawach rozdziatu funduszy unijnych na przykładzie rozdziału środków w ramach polityki rozwoju, „Zeszyty Naukowe Sądownictwa Administracyjnego" 2011, nr 6 (39), s. 79.

13 L. Kieres, Zagadnienia wprowadzajace, [w:] Administracyjne prawo gospodarcze, red. L. Kieres, Wrocław 2005, s. 12. Por. M. Guziński, T. Kocowski, Regulacja prawna gospodarowania mieniem publicznym, [w:] Prawo administracyjne, red. J. Boć, Wrocław 2010, s. 311; zob. K. Kokocińska, Problematyka pogranicza prawa - refleksje nad istota publicznego prawa gospodarczego, [w:] Państwo a gospodarka. Zasady — instytucje — procedury. Księga Jubileuszowa dedykowana Profesor Bożenie Popowskiej, red. P. Lissoń, M. Strzelbicki, Poznań 2020, s. 99.

14 A. Chełmoński, Zasady publicznego prawa gospodarczego, [w:] Zasady prawa gospodarczego. Materiały konferencyjne, red. A. Śmieja, Wrocław 1999, s. 43. Zob. A. Powałowski, Wprowadzenie do aksjologii prawa gospodarczego publicznego, [w:] Państwo a przedsiębiorca..., s. 221.

15 A. Chełmoński, Swoiste zasady administracyjnego prawa gospodarczego, [w:] Administracyjne prawo gospodarcze..., s. 64.

16 L. Adam, Rodzaje kontroli finansowej, [w:] L. Adam, J. Pięta, Kontrola finansowa wedtug stanu prawnego (ogłoszonego) na 31 grudnia 1970 r., Wrocław 1971, s. 17; L. Murat, Rzetelność jako prawne i pozaprawne kryterium kontroli, „Kontrola Państwowa” 2014, nr 4, s. 60. 
tuje $^{17}$. Realizacja zasady prawidłowego gospodarowania mieniem publicznym, zdaniem A. Chełmońskiego ${ }^{18}$, jest przedmiotem obszernej sfery przepisów prawa finansowego - zwłaszcza prawa budżetowego, a także przepisów pokrewnych, jak na przykład prawo dotyczące inwestycji, zamówień publicznych, przetargów. Wszystkie one określają wzorzec zachowań dla organów władzy publicznej na tym obszarze i są zarazem punktem odniesienia do działań kontrolnych i nadzorczych wobec organów gospodarujących tym mieniem ${ }^{19}$.

Istotne znaczenie zamówień publicznych dla społecznej gospodarki rynkowej jest akcentowane w piśmiennictwie przedmiotu ${ }^{20}$ oraz procesie legislacyjnym $^{21}$. Dziedzina zamówień publicznych to potężne narzędzie wspierające rozwój gospodarczy, umożliwiające poprawę jakości zamawianych dostaw, i robót budowlanych, wsparcie innowacyjności, realizowanie polityki społecznej i strategii państwa.

Zamówienia publiczne są kluczową formą udziału sektora publicznego w gospodarce. Wartość zamówień udzielanych w procedurach przewidzianych w p.z.p. 2014 to około 163,2 mld złotych w 2017 roku, co stanowi około 8,23\% PKB (w 2016 roku: 107 mld złotych, 5,8\% PKB). Przybliżona wartość rynku zamówień publicznych, uwzględniająca również zamówienia udzielane bez stosowania procedur, wyniosła 234,6 mld złotych w 2017 roku (174,3 mld złotych w 2016 roku). Zamówienia publiczne wywierają bezpośredni i natychmiastowy wpływ na krajową gospodarkę, w tym jej najistotniejsze branże. Sektor usług oraz produkcja przemysłowa powiązana $\mathrm{z}$ budownictwem $\mathrm{i}$ infrastrukturą $\mathrm{w}$ znacznej mierze zależne są od rynku zamówieńn 22 .

W wielu branżach dla co czwartego przedsiębiorcy zamówienia publiczne stanowią ponad połowę całkowitych przychodów, dla zaś co dziesiątego to $75 \%$ przychodów. Odpowiednio ukierunkowane i zarządzane zamówienia publiczne mogą tym samym być ważnym czynnikiem wzrostu przedsiębiorstw. Natomiast źle przeprowadzane postępowania, brak współpracy między zamawiającym a wykonawcą czy restrykcyjne umowy mogą prowadzić do upadku firm lub ich przechodzenia na inne rynki. Dlatego też tak istotne jest wprowadzanie usprawnień proceduralnych ułatwiających przedsiębiorcom, w szczególności z sektora MŚP,

17 A. Chełmoński, Swoiste zasady..., s. 64.

18 Ibidem. Zob. K. Horubski, Zasada prawidłowego gospodarowania mieniem publicznym w publicznym prawie gospodarczym - zagadnienia wybrane, [w:] Państwo a gospodarka..., s. 81 .

19 Ibidem, s. 64. Por. Prawo zamówień publicznych, red. M. Guziński, Wrocław 2008; B. Błasiak-Nowak, M. Rajczewska, Kontrola zewnętrzna systemów zarządzania i kontroli programów operacyjnych wspólfinansowanych z budżetu Unii Europejskiej, „Kontrola Państwowa” 2009, nr 6, s. 3.

20 A. Panasiuk, System zamówień publicznych. Zarys wyktadu, Warszawa 2013, s. 22. Zob. M. Małecka-Łyszczek, Efektywność zamówień publicznych $w$ świetle kontroli zarządczej-uwagi wybrane, [w:] Państwo a przedsiębiorca..., s. 569.

21 Prezes Rady Ministrów RM-10-122-19, druk nr 3624 z dnia 12 lipca 2019 roku.

22 Uzasadnienie projektu ustawy z dnia 11 września 2019 roku Prawo zamówień publicznych (Dz.U. poz. 2019) — Prezes Rady Ministrów RM-10-122-19... 
dostęp do zamówień. Obecna ustawa p.z.p. nie ma wydzielonej części zamówień klasycznych poniżej i powyżej progów unijnych, a tryby i zasady udzielania zamówień krajowych właściwie nie różnią się od zamówień unijnych. W nowej ustawie proponuje się wyodrębnienie oraz znaczące uproszczenie i uelastycznienie procedury udzielania zamówień poniżej progów unijnych przez odejście od stosowania trybów właściwych do zamówień powyżej progów unijnych i zwiększenie autonomii zamawiającego w kształtowaniu procedury wyłonienia wykonawcy ${ }^{23}$.

Zamówienia publiczne są narzędziem kształtowania gospodarki państwa, w tym realizacji celów społecznych, politycznych i strategicznych, służącym wspieraniu ważnych gałęzi rynku. Procedura zawarta w ustawie, przez odpowiednie kształtowanie wymagań, może być najbardziej efektywnym wsparciem celów gospodarczych i rozwojowych oraz znaczących polityk społecznych i związanych $\mathrm{z}$ rynkiem pracy.

Zastosowanie odpowiednich kryteriów oceny ofert, trybów udzielania zamówień oraz rzetelna współpraca $\mathrm{z}$ wykonawcą powinny nie tylko zapewniać równe traktowanie, konkurencyjność i oszczędności, lecz także kreować zapotrzebowanie oraz pożądane postawy, wzmacniać kompetencje zespołów, umożliwiać budowanie doświadczenia wykonawców oraz dawać impuls do rozwoju.

Istotnym bodźcem do poprawy efektywności zamówień publicznych, ich transparentności oraz dostępu małych i średnich przedsiębiorstw do zamówień publicznych jest elektronizacja procesu udzielania zamówienia publicznego, w szczególności obowiązek udostępniania przez zamawiających dokumentów zamówienia w postaci elektronicznej oraz prowadzenia komunikacji elektronicznej między zamawiającym a wykonawcą. Dzięki obowiązkowi przyjmowania przez zamawiających dokumentów składanych drogą elektroniczną zmniejszają się koszty udziału w postępowaniu po stronie wykonawców. Elektronizacja obniża też koszty prowadzenia postępowań po stronie zamawiających w związku z brakiem konieczności przechowywania znacznej liczby dokumentów w postaci papierowej. Jak wynika z badań przeprowadzonych przez Komisję Europejską, wprowadzenie elektronicznego procesu udzielania zamówień generuje oszczędności po stronie instytucji zamawiających sięgające nawet $20 \%$ dotychczasowych wydatków ${ }^{24}$.

Projektodawca p.z.p. 2019 wskazuje, że przygotowanie nowej ustawy wychodzi naprzeciw wieloletnim oczekiwaniom zarówno podmiotów publicznych, jak i wykonawców ubiegających się o zamówienia publiczne. Ponad czternastoletni okres obowiązywania ustawy p.z.p. 2004, uchwalonej w zupełnie innych realiach gospodarczych oraz otoczeniu prawnym, a także wprowadzane liczne zmiany na skutek transpozycji dyrektyw unijnych oraz pozostałe modyfikacje mające na celu dostosowywanie prawa do potrzeb zmieniającej się sytuacji prawnej

23 Ibidem.

24 Ibidem. 
i gospodarczej generują potrzebę przygotowania nowego kompleksowego i spójnego Prawa zamówień publicznych.

Celem przygotowania p.z.p. 2019 było wprowadzenie nowych rozwiązań opartych na maksymalnej efektywności i przejrzystości udzielanych zamówień publicznych, uwzględniających jednocześnie rolę zamówień publicznych w kształtowaniu polityki państwa oraz potrzebę wsparcia rozwoju małych i średnich przedsiębiorstw, a także innowacyjnych, nowoczesnych produktów i usług. Konieczne stało się również zwiększenie przejrzystości i spójności regulacji w zakresie zamówień publicznych ${ }^{25}$. Projekt p.z.p. 2019 jest także odpowiedzią na wyzwanie postawione w Strategii na rzecz odpowiedzialnego rozwoju, w której wskazano, że zamówienia publiczne są jednym z obszarów, których usprawnienie może przyczynić się do zapewnienia stałego wzrostu gospodarczego kraju przez prowadzenie zrównoważonej polityki gospodarczej sprzyjającej zapobieganiu wykluczeniu społecznemu i gospodarczemu.

Opracowanie p.z.p. 2019 zostało poprzedzone szerokimi konsultacjami Koncepcji nowego Prawa zamówień publicznych z dnia 6 czerwca 2018 roku (dalej: Koncepcja Prawa zamówień publicznych), w której zdiagnozowano główne obszary identyfikujące potrzebę wprowadzenia nowych rozwiązań optymalizujących proces udzielania zamówień. Koncepcja Prawa zamówień publicznych została przygotowana wspólnie przez ministra przedsiębiorczości i technologii oraz Prezesa Urzędu Zamówień Publicznych, a następnie poddana konsultacjom ${ }^{26}$. Wskazano w niej na kluczowe problemy w dziedzinie zamówień publicznych wymagające nowych rozwiązań, które zostały zaprojektowane w p.z.p. 2019:

1. niepowiązanie wydatków z realizacją polityki oraz celów strategicznych państwa;

2. wybieranie rozwiązań najtańszych zamiast najbardziej efektywnych w dłuższym okresie;

3. nieproporcjonalny do potencjału udział przedsiębiorców z sektora MŚP w rynku zamówień publicznych;

4. nieefektywne zarządzanie procesem zakupowym — od planowania udzielenia zamówienia, przygotowania postępowania, po podsumowanie jego realizacji;

5. koncentracja zamawiających na spełnieniu wymogów formalnych zamiast na uzyskaniu najlepszego jakościowo produktu lub usługi;

6. niski odsetek zamówień udzielonych w innych trybach niż przetarg nieograniczony i z wolnej ręki (negocjacje z ogłoszeniem, dialog konkurencyjny, negocjacje bez ogłoszenia oraz partnerstwo innowacyjne i licytacja elektroniczna to zaledwie $1,27 \%$ postępowań);

26 Ibidem. 
7. zmniejszające się zainteresowanie wykonawców rynkiem zamówień publicznych (w 2017 roku w około 43\% postępowań została złożona tylko jedna oferta);

8. ograniczona dostępność do środków odwoławczych do Krajowej Izby Odwoławczej (KIO) oraz skarg na wyroki KIO do sądów powszechnych;

9. niejednolitość orzecznictwa KIO i sądów powszechnych w przedmiocie zamówień publicznych;

10. brak wyodrębnionej i uproszczonej procedury udzielania zamówień poniżej progów unijnych;

11. rozproszony i nieefektywny system kontroli;

12. brak przejrzystości ustawy wywołany licznymi nowelizacjami ${ }^{27}$.

Powyższe uzasadnia stwierdzenie, że zamówienia publiczne w gospodarce społecznej gospodarce rynkowej opartej na wolności działalności gospodarczej, własności prywatnej oraz solidarności, dialogu i współpracy partnerów społecznych — odgrywają istotną rolę. Już w pierwszej fazie formowania rozwiązań prawnych znamiennych dla systemów gospodarek rynkowych, po okresie państwa komunistycznego, przyjęto w naszym kraju między innymi pod wpływem zobowiązań wynikających z okresu przedakcesyjnego unormowania w zakresie zamówień publicznych zawarte w u.z.p. 1994, nawiązujące do prawodawstwa byłych Wspólnot Europejskich $^{28}$. Zmienność celów stawianych przed zamówieniami publicznymi i naturalna niestabilność stosunków społecznych w obrębie gospodarowania skutkują potrzebą zmian czy koniecznością przyjmowania nowych regulacji prawnych. Ustawa p.z.p. 2019 ma wyjść naprzeciw dotychczasowym niedomaganiom wynikającym z aplikowania p.z.p. 2004 oraz realizować aktualne postulaty polityki gospodarczej. Od pojawienia się w systemie prawnym norm mających za przedmiot zamówienia publiczne jurysprudencja analizuje występujące tam zjawiska prawne. Ma to miejsce przede wszystkim w obrębie prawa zarządu mieniem publicznym, które przynależy do publicznego prawa gospodarczego.

\section{Ewolucja pozycji prawnej i zadań Prezesa Urzędu Zamówień Publicznych}

Już wstępny ogląd — zestawienie — interesujących nas fragmentów materiału normatywnego pozwala zaobserwować zachodzące przemiany w obrębie

27 Ibidem. Por. R. Szostak, Z problematyki racjonalizacji ograniczeń swobody kontraktowej w zamówieniach publicznych, [w:] Państwo a przedsiębiorca..., s. 603.

28 A. Walaszek-Pyzioł, Wprowadzenie, [w:] M. Biliński et al., op. cit., s. 7. Por. L. Bar, Ksztattowanie ordynacji rynkowych (rozważania $w$ drodze do Wspólnoty Europejskiej), „Państwo i Prawo" 1992, nr 11, s. 36; L. Kieres, Stowo wstępne, [w:] Państwo a przedsiębiorca..., s. 13. 
pozycji prawnej i zadań Prezesa Urzędu Zamówień Publicznych w systemie administracji publicznej29.

Ustawa u.z.p. 1994 obejmowała 97 podstawowych jednostek redakcyjnych (artykułów) oraz 11 stron Dziennika Ustaw. W art. 1 stanowiła między innymi, że określa organ właściwy w sprawach o zamówienia publiczne. Prezes Urzędu Zamówień Publicznych (dalej: Prezes UZP, Prezes Urzędu) był centralnym organem administracji państwowej właściwym w sprawach zamówień publicznych w zakresie określonym ustawą. Nadzór nad Prezesem Urzędu sprawował minister właściwy do spraw administracji publicznej, a Prezesa Urzędu powoływał Prezes Rady Ministrów na wniosek ministra właściwego do spraw administracji publicznej; odwoływał go natomiast Prezes Rady Ministrów. Do zakresu działania Prezesa Urzędu na gruncie u.z.p. 1994 należało przede wszystkim:

1. zatwierdzanie wyboru trybu udzielania zamówienia publicznego innego niż przetarg nieograniczony;

2. ustalanie i prowadzenie listy arbitrów rozpatrujących odwołania wniesione w postępowaniu o zamówienie publiczne, a także ogłaszanie listy arbitrów w Biuletynie Zamówień Publicznych;

3. składanie Radzie Ministrów rocznego sprawozdania o funkcjonowaniu systemu zamówień publicznych;

4. opracowywanie projektów przepisów prawnych dotyczących zamówień publicznych;

5. upowszechnianie ogólnych warunków umów w sprawach o zamówienia publiczne, wzorów umów, regulaminów oraz wzorców postępowania przy udzielaniu zamówienia, na wniosek i w porozumieniu z właściwymi ministrami;

6. gromadzenie informacji o planach zamówień publicznych, zawartych umowach oraz realizacji zamówień publicznych;

7. opracowywanie programów szkoleń dotyczących zamówień publicznych oraz organizowanie i inspirowanie szkoleń;

8. współpraca międzynarodowa w sprawach związanych z zamówieniami publicznymi;

9. wydawanie Biuletynu Zamówień Publicznych;

10. przekazywanie do publikacji w Dzienniku Urzędowym Wspólnot Europejskich ogłoszeń o zamówieniach publicznych;

11. publikowanie w Biuletynie Zamówień Publicznych na podstawie otrzymanych ogłoszeń informacji zbiorczych o dostawcach lub wykonawcach, którym w poprzednim roku udzielone zostało zamówienie publiczne o wartości zamówienia przekraczającej wyrażoną w złotych równowartość kwoty 500 tys. euro;

12. prowadzenie listy organizacji pracodawców i przedsiębiorców zrzeszających dostawców lub wykonawców uprawnionych do wnoszenia środków odwoławczych.

29 Por. E. Anioł, Środki ochrony prawnej w świetle nowego prawa zamówień publicznych zagadnienia wybrane, [w:] Państwo a przedsiębiorca..., s. 535. 
Z kolei p.z.p. 2004 obejmuje już 227 artykułów oraz 44 stron Dziennika Ustaw. W art. 1 stanowi, że określa zasady i tryb udzielania zamówień publicznych, środki ochrony prawnej, kontrolę udzielania zamówień publicznych oraz organy właściwe w sprawach uregulowanych w ustawie. Prezes UZP jest centralnym organem administracji rządowej właściwym w sprawach zamówień publicznych. Prezesa Urzędu powołuje Prezes Rady Ministrów spośród kandydatów wyłonionych w drodze otwartego konkursu. Nadzór nad Prezesem Urzędu sprawuje Prezes Rady Ministrów, następnie nadzór ten zostaje przekazany ministrowi właściwemu do spraw gospodarki. Prezes Urzędu jest powoływany przez ministra właściwego do spraw gospodarki spośród osób wyłonionych w drodze otwartego i konkurencyjnego naboru; minister właściwy do spraw gospodarki odwołuje Prezesa Urzędu. Ustawa p.z.p. 2004 w zakresie działania Prezesa UZP wskazuje, że:

1. opracowuje on projekty aktów normatywnych dotyczących zamówień;

2. podejmuje rozstrzygnięcia $\mathrm{w}$ indywidualnych sprawach przewidzianych ustawą;

3. wydaje w formie elektronicznej Biuletyn Zamówień Publicznych, w którym zamieszczane są ogłoszenia przewidziane ustawą;

4. prowadzi i ogłasza na stronie internetowej Urzędu listę organizacji uprawnionych do wnoszenia środków ochrony prawnej;

5. zapewnia funkcjonowanie systemu środków ochrony prawnej;

6. opracowuje programy szkoleń, organizuje oraz inspiruje szkolenia z zakresu zamówień;

7. przygotowuje i upowszechnia przykładowe kryteria oceny merytorycznego poziomu szkoleń;

8. przygotowuje i upowszechnia przykładowe wzory umów w sprawach zamówień publicznych, regulaminów oraz innych dokumentów stosowanych przy udzielaniu zamówień;

9. czuwa nad przestrzeganiem zasad systemu zamówień, w szczególności dokonuje kontroli procesu udzielania zamówień w zakresie przewidzianym ustawą;

10. upowszechnia zasady etyki zawodowej osób wykonujących zadania w systemie zamówień;

11. dąży do zapewnienia jednolitego stosowania przepisów o zamówieniach przy uwzględnieniu orzecznictwa sądów oraz Trybunału Konstytucyjnego, w szczególności upowszechnia orzeczenia Krajowej Izby Odwoławczej, sądów oraz Trybunału Konstytucyjnego dotyczące zamówień;

12. prowadzi współpracę międzynarodową w sprawach związanych z zamówieniami;

13. dokonuje analiz funkcjonowania systemu zamówień;

14. opracowuje i przedstawia Radzie Ministrów, Komisji Europejskiej oraz właściwej komisji Sejmu roczne sprawozdania o funkcjonowaniu systemu zamówień;

15. przekazuje co trzy lata Komisji Europejskiej sprawozdanie z monitorowania funkcjonowania systemu zamówień oraz sprawozdanie statystyczne doty- 
czące zamówień, których wartość jest mniejsza niż kwoty określone w przepisach wydanych na podstawie art. 11 ust. 8 p.z.p. 2004;

16. przedstawia ministrowi właściwemu do spraw gospodarki roczną informację o działaniu Krajowej Izby Odwoławczej, uwzględniającą problemy wynikające z orzecznictwa;

17. zgłasza kandydatów na Prezesa i wiceprezesa KIO;

18. zgłasza wniosek o powołanie rzecznika dyscyplinarnego KIO;

19. prowadzi działania związane $\mathrm{z}$ informatyzacją systemu zamówień publicznych;

20. przekazuje Komisji Europejskiej co roku do dnia 31 marca wyroki KIO z roku poprzedniego dotyczące odwołań w sprawie postępowań o udzielenie zamówienia, w których nie orzeczono unieważnienia umowy ze względu na ważny interes publiczny, o którym mowa w art. 192 p.z.p. 2004, wraz z ich uzasadnieniem.

Natomiast p.z.p. 2019 to 623 artykuły oraz 153 strony Dziennika Ustaw. $\mathrm{W}$ art. 1 pkt 7 stanowi ona przykładowo, iż przedmiotem jej regulacji są między innymi organy właściwe do spraw zamówień. Należą do nich: Prezes Urzędu, Krajowa Izba Odwoławcza, Komitet do spraw Kontroli w Zamówieniach Publicznych oraz Rada Zamówień Publicznych. Na gruncie p.z.p. 2019 Prezes UZP jest centralnym organem administracji rządowej właściwym w sprawach zamówień. Nadzór nad Prezesem Urzędu sprawuje minister właściwy do spraw gospodarki. Prezes Urzędu jest powoływany i odwoływany przez ministra właściwego do spraw gospodarki. Prezes Urzędu na gruncie p.z.p. 2019 przede wszystkim:

1. czuwa nad systemem zamówień, w szczególności nad przestrzeganiem zasad udzielania zamówień, dokonuje kontroli procesu udzielania zamówień w zakresie przewidzianym ustawą oraz upowszechnia zasady etyki zawodowej osób wykonujących zadania w systemie zamówień;

2. podejmuje rozstrzygnięcia $w$ indywidualnych sprawach przewidzianych ustawą;

3. prowadzi współpracę międzynarodową w sprawach związanych z zamówieniami;

4. dokonuje analiz funkcjonowania systemu zamówień;

5. opracowuje i opiniuje projekty aktów normatywnych dotyczących zamówień;

6. dąży do zapewnienia jednolitego stosowania przepisów o zamówieniach przy uwzględnieniu orzecznictwa sądów oraz trybunałów, przede wszystkim upowszechnia orzeczenia Krajowej Izby Odwoławczej, sądów powszechnych, Sądu Najwyższego, Trybunału Sprawiedliwości Unii Europejskiej oraz Trybunału Konstytucyjnego dotyczące zamówień;

7. przygotowuje i upowszechnia przykładowe wzory umów w sprawach zamówień publicznych, regulaminów oraz innych dokumentów stosowanych przy udzielaniu zamówień; 
8. przygotowuje na podstawie orzecznictwa KIO i sądu zamówień publicznych oraz podaje do publicznej wiadomości przykładowe postanowienia umowne;

9. prowadzi działalność edukacyjno-informacyjną w zakresie zamówień;

10. udziela informacji z zakresu zamówień przy pomocy centrum telefonicznego oraz przy użyciu środków komunikacji elektronicznej;

11. upowszechnia wiedzę o zamówieniach, w tym w zakresie informacji analitycznych;

12. prowadzi działania związane z informatyzacją systemu zamówień;

13. wydaje w formie elektronicznej Biuletyn Zamówień Publicznych, w którym zamieszczane są ogłoszenia przewidziane ustawą;

14. zapewnia funkcjonowanie systemu środków ochrony prawnej w zakresie postępowania odwoławczego;

15. prowadzi i ogłasza na stronie internetowej Urzędu listę organizacji uprawnionych do wnoszenia środków ochrony prawnej;

16. zgłasza kandydatów na Prezesa i wiceprezesów Krajowej Izby Odwoławczej;

17. zgłasza wniosek o powołanie rzecznika dyscyplinarnego KIO;

18. przedstawia ministrowi właściwemu do spraw gospodarki do zatwierdzenia, w terminie do dnia 31 października każdego roku, plan sposobu wykonania zadań określonych w pkt 7 i 9 w kolejnym roku kalendarzowym;

19. przedstawia ministrowi właściwemu do spraw gospodarki sprawozdanie z działalności Krajowej Izby Odwoławczej za poprzedni rok kalendarzowy, uwzględniające problemy wynikające z jej orzecznictwa;

20. opracowuje i przedstawia Radzie Ministrów, w terminie do dnia 31 lipca każdego roku, oraz właściwej komisji sejmowej sprawozdanie z funkcjonowania systemu zamówień, $\mathrm{w}$ tym $\mathrm{w}$ zakresie realizacji zadań, o których mowa $\mathrm{w}$ pkt 6 i 7, w poprzednim roku kalendarzowym, uwzględniając w nim analizę swojej działalności;

21. przekazuje Komisji Europejskiej co trzy lata sprawozdanie z monitorowania funkcjonowania systemu zamówień oraz sprawozdanie statystyczne dotyczące zamówień, których wartość jest mniejsza niż progi unijne;

22. przekazuje Komisji Europejskiej co roku, do dnia 31 marca, wyroki KIO z poprzedniego roku kalendarzowego dotyczące odwołań w sprawie postępowań o udzielenie zamówienia, w których nie orzeczono unieważnienia umowy ze względu na ważny interes publiczny, o którym mowa w art. 554 ust. 3 pkt 2 lit. c p.z.p. 2019, wraz z ich uzasadnieniem;

23. przedstawia stanowisko $\mathrm{w}$ związku $\mathrm{z}$ wątpliwościami interpretacyjnymi między organami kontroli, o których mowa w art. 596 ust. 2 p.z.p. 2019, na wniosek organu kontroli;

24. opiniuje kwestionariusz kontroli, o którym mowa w art. 599 ust. 1 p.z.p. 2019, o ile organ kontroli zwróci się do niego o wydanie opinii. 


\section{Wnioski}

Analizowana regulacja prawna znacznie się rozwinęła, formalnie zwiększyła się z 97 artykułów i 11 stron Dziennika Ustaw w 1994 roku do 623 artykułów i 153 stron w 2019 roku. W wyniku tego nastąpił niebywały przyrost merytorycznych wypowiedzi normatywnych z dziedziny zamówień publicznych, nad których przestrzeganiem czuwa Prezes UZP.

Przeprowadzone rozważania dotyczące wybranych elementów pozycji prawnej i zadań Prezesa Urzędu na gruncie u.z.p. 1994, p.z.p. 2004 oraz p.z.p. 2019 potwierdzają powiększenie zakresu jego powinności (zadań, kompetencji) sformułowanych w kolejnych ustawach. Powierzanie temu organowi administracji publicznej coraz to nowych zadań miało miejsce także już na podstawie p.z.p. 2004. Tym samym elementem zmian wprowadzonych przez p.z.p. 2019 jest dalsze wzmocnienie w tym aspekcie pozycji Prezesa Urzędu Zamówień Publicznych. W nowej roli Prezes UZP będzie — w szerszym zakresie niż do tej pory — wspierał zamawiających przez systematyczne wypracowywanie wzorów umów i innych dokumentów, a także gromadzenie dobrych praktyk. Ponadto rozszerzona została funkcja doradcza Prezesa UZP, między innymi przez stworzenie w urzędzie obsługującym ten organ, to jest Urzędzie Zamówień Publicznych, infolinii ${ }^{30}$. Prezes UZP jest centralnym organem administracji rządowej właściwym w sprawach zamówień publicznych. Z punktu widzenia prawa ustrojowego pierwotnie (u.z.p. 1994) zwierzchnictwo administracyjne wobec Prezesa Urzędu sprawował Prezes Rady Ministrów, następnie minister właściwy do spraw gospodarki. Z perspektywy metod i form działania administracji publicznej wykorzystywane są do realizacji odnośnych zadań różnej natury środki (instrumenty) działania: władcze i niewładcze, czynności organizatorskie i materialno-techniczne itp.

Należy podkreślić, że niezależnie od tego do systemu zamówień publicznych p.z.p. 2019 wprowadza nowy organ administracji publicznej. Jest to Komitet do spraw Kontroli w Zamówieniach Publicznych, który ma pełnić funkcje doradcze wobec ministra właściwego do spraw gospodarki. Na płaszczyźnie czysto jurydycznej wyraża się to przyrostem i modyfikacją odpowiednich norm prawa administracyjnego (ustrojowego, materialnego i proceduralnego). Ponadto właściwymi organami administracji publicznej spoza regulacji p.z.p. 2019 — w określonych aspektach zamówień publicznych — są także na mocy odrębnych ustaw na przykład regionalne izby obrachunkowe, Centralne Biuro Antykorupcyjne, organy orzekające w sprawach o naruszenie dyscypliny finansów publicznych czy odpowiednie organy Krajowej Administracji Skarbowej. Przeprowadzone rozważania świadczą przede wszystkim o niepomijalności Prezesa UZP, ale też administracji publicznej w zamówieniach publicznych w społecznej gospodarce rynkowej.

30 Ibidem. 


\section{Bibliografia}

Adam L., Rodzaje kontroli finansowej, [w:] L. Adam, J. Pięta, Kontrola finansowa wedlug stanu prawnego (ogłoszonego) na 31 grudnia 1970 r., Wrocław 1971.

Anioł E., Środki ochrony prawnej w świetle nowego prawa zamówień publicznych — zagadnienia wybrane, [w:] Państwo a przedsiębiorca — aktualne wyzwania, red. A. Borkowski, W. Małecki, Wrocław 2019.

Bar L., Kształtowanie ordynacji rynkowych (rozważania w drodze do Wspólnoty Europejskiej), „Państwo i Prawo” 1992, nr 11.

Bigo T., Wytyczne dla prawa administracyjnego w Konstytucji Polskiej r. 1935, Warszawa 1936.

Błasiak-Nowak B., Rajczewska M., Kontrola zewnętrzna systemów zarządzania i kontroli programów operacyjnych wspólfinansowanych z budżetu Unii Europejskiej, „Kontrola Państwowa” 2009 , nr 6.

Boć J., Konstytucja a prawo administracyjne, „Ruch Prawniczy, Ekonomiczny i Socjologiczny” 2011, nr 2.

Chełmoński A., Swoiste zasady administracyjnego prawa gospodarczego, [w:] Administracyjne prawo gospodarcze, red. L. Kieres, Wrocław 2005.

Chełmoński A., Zasady publicznego prawa gospodarczego, [w:] Zasady prawa gospodarczego. Materiaty konferencyjne, red. A. Śmieja, Wrocław 1999.

Dhugosz T. et al., Funkcje administracji gospodarczej, [w:] System Prawa Administracyjnego, t. 8a. Publiczne prawo gospodarcze, red. J. Grabowski, L. Kieres, A. Walaszek-Pyzioł, Warszawa 2018.

Dzierżanowski W., Prawo do sądu w zamówieniach publicznych, Warszawa 2018.

Gola J., Między gospodarnościa a niegospodarnościa działań organów administracji gospodarczej, [w:] Państwo a przedsiębiorca - aktualne wyzwania, red. A. Borkowski, W. Małecki, Wrocław 2019.

Guziński M., Organy administracji publicznej jako podmioty zamówień publicznych, [w:] Między tradycja a przyszłościa w nauce prawa administracyjnego. Ksiega jubileuszowa Profesora Jana Bocia, red. J. Supernat, Wrocław 2009.

Guziński M., Kocowski T., Regulacja prawna gospodarowania mieniem publicznym, [w:] Prawo administracyjne, red. J. Boć, Wrocław 2010.

Hełczyński B., Komercjalizacja przedsiębiorstw państwowych na tle polskich przepisów prawnych, Warszawa 1929.

Horubski K., Zasada prawidlowego gospodarowania mieniem publicznym $w$ publicznym prawie gospodarczym - zagadnienia wybrane, [w:] Państwo a gospodarka. Zasady — instytucje procedury. Księga Jubileuszowa dedykowana Profesor Bożenie Popowskiej, red. P. Lissoń, M. Strzelbicki, Poznań 2020.

Jeżewski J., Administracja pod rzadem prawa cywilnego, Wrocław 1974.

Kieres L., Konstytucyjne publiczne prawo gospodarcze, [w:] M. Biliński et al., Wielka encyklopedia prawa, t. 17. Prawo publiczne gospodarcze, Warszawa 2019.

Kieres L., Stowo wstępne, [w:] Państwo a przedsiębiorca - aktualne wyzwania, red. A. Borkowski, W. Małecki, Wrocław 2019.

Kieres L., Zagadnienia wprowadzające, [w:] Administracyjne prawo gospodarcze, red. L. Kieres, Wrocław 2005.

Kokocińska K., Problematyka pogranicza prawa - refleksje nad istota publicznego prawa gospodarczego, [w:] Państwo a gospodarka. Zasady — instytucje — procedury. Ksiega Jubileuszowa dedykowana Profesor Bożenie Popowskiej, red. P. Lissoń, M. Strzelbicki, Poznań 2020.

Kopiński D., Teoretyczne podstawy globalnych dóbr publicznych (GDP), [w:] D. Kopiński, M. Wróblewski, Globalne dobra publiczne a organizacje międzynarodowe. Przypadek Banku Światowego i Międzynarodowego Funduszu Walutowego, Warszawa 2020. 
Limperg B., Zaufanie i rzady prawa, [w:] Przyszłość Europy opartej na rządach prawa, „Studia i Analizy Sądu Najwyższego. Materiały Naukowe" 8, 2019.

Małecka-Łyszczek M., Efektywność zamówień publicznych w świetle kontroli zarzadczej - uwagi wybrane, [w:] Państwo a przedsiębiorca — aktualne wyzwania, red. A. Borkowski, W. Małecki, Wrocław 2019.

Murat L., Rzetelność jako prawne i pozaprawne kryterium kontroli, „Kontrola Państwowa” 2014, nr 4. Niewiadomski Z., System planowania i zagospodarowania przestrzennego a ustawy specjalne. Dezintegracja systemu? — tezy wstapienia, [w:] Specustawy inwestycyjno-budowlane, red. T. Bąkowski, Gdańsk 2020.

Panasiuk A., System zamówień publicznych. Zarys wykładu, Warszawa 2013.

Powałowski A., Wprowadzenie do aksjologii prawa gospodarczego publicznego, [w:] Państwo a przedsiębiorca - aktualne wyzwania, red. A. Borkowski, W. Małecki, Wrocław 2019.

Prawo zamówień publicznych, red. M. Guziński, Wrocław 2008.

Przeszło E., Rola organizacji przedsiębiorców w sferze zamówień publicznych, [w:] Państwo a przedsiębiorca - aktualne wyzwania, red. A. Borkowski, W. Małecki, Wrocław 2019.

Rozmaryn S., Konstytucja jako ustawa zasadnicza Polskiej Rzeczypospolitej Ludowej, Warszawa 1961.

Sajo A., Uitz R., The Constitution of Freedom. An Introduction to Legal Constitutionalism, Oxford 2017.

Sawczuk W.S., Właściwość sądów administracyjnych i sadów powszechnych w sprawach rozdziału funduszy unijnych na przykładzie rozdziału środków w ramach polityki rozwoju, „Zeszyty Naukowe Sądownictwa Administracyjnego" 2011, nr 6 (39).

Strzyczkowski K., Prawa podstawowe jako źródło celów społecznych i gospodarczych Unii Europejskiej, [w:] Państwo a przedsiębiorca - aktualne wyzwania, red. A. Borkowski, W. Małecki, Wrocław 2019.

Szostak R., Z problematyki racjonalizacji ograniczeń swobody kontraktowej w zamówieniach publicznych, [w:] Państwo a przedsiębiorca - aktualne wyzwania, red. A. Borkowski, W. Małecki, Wrocław 2019.

Szyszkowski S.Z., Kapitały obrotowe w skomercjalizowanych przedsiębiorstwach państwowych, „Ruch Prawniczy, Ekonomiczny i Socjologiczny” 1929, pierwsze półrocze.

Walaszek-Pyzioł A., Wprowadzenie, [w:] M. Biliński et al., Wielka encyklopedia prawa, t. 17. Prawo publiczne gospodarcze, Warszawa 2019.

\title{
Unavoidability of the President of the Public Procurement Office in the system of awarding public contracts
}

\author{
Summary
}

Public procurement law is a part of public economic law, known in legal doctrine as law of public property management. The President of the Public Procurement Office is the central organ of the government administration endowed with jurisdiction over matters of public contracts. The legal status of the President has been strengthened by the Public Procurement Act 2019. Accordingly, the article underlies the unavoidability of the President in the system of awarding public contracts in the social market economy.

Keywords: President of the Public Procurement Office, public contracts. 